\title{
1. Compliance in international human rights law: issues, concept, methodology
}

\author{
Rainer Grote, Mariela Morales Antoniazzi and Davide Paris
}

\section{INTRODUCTION}

Robert Howse and Ruti Teitel have pointed out that in most fields of legal studies, the question of why, how, and to what extent the actors bound by legal rules comply with them has been a secondary, if not marginal, one for scholarly inquiries by jurists'. ${ }^{1}$ In their view, 'international law is a striking exception' because 'the conceptual, and more recently empirical, study of compliance has become a central preoccupation, and perhaps the fastest growing subfield, in international legal scholarship'. ${ }^{2}$ Other concepts, like enforcement and implementation, that have largely been shaped by the practice and context of domestic legal systems, fail to capture the peculiarity of the decentralized system of international law, where no autonomous superior authority exists that can force states to fulfil the legal obligations they have signed up to, as is the case in domestic legal systems where the state's monopoly of force underpins the mechanisms designed to render legal norms effective. A focus on compliance, therefore, aims to demonstrate the effectiveness of international law by showing that "there is a range of considerations, including reputational effects and long-term self-interest, that lead to compliance with international law regardless of the absence of authoritative interpretation and enforcement in most instances'. 3

This observation is of particular interest to the study of international human rights law (IHRL). The main reason for this is that IHRL, unlike most other international law, does not primarily aim to shape the conduct of states in the international arena. Rather more ambitiously, it creates obligations for states to secure the full enjoyment of the rights listed in the human rights treaty for their citizens and inhabitants in the domestic sphere by all adequate and necessary means, including legislative, executive, and judicial action. In other words, compliance in IHRL is not situated at the interface of international law and international politics, but at the interface of international law and politics with domestic law and politics.

In order to monitor state compliance with the treaty obligations, the human rights treaties regularly set up special bodies and institutions which are given the mandate to monitor, supervise, and, in some cases, sanction state behavior that is in conflict with those treaty commitments. These institutions come in a variety of forms and outlooks, from the UN Human Rights Council which is charged with monitoring the compliance with UN human rights law through a system combining the review of periodic national reports with more topical and ad-hoc 


\section{Research handbook on compliance in international human rights law}

review mechanisms, to similarly designed systems of peer review and pressure exercised by specialized monitoring bodies under the various UN human rights treaties.

However, the most elaborate institutional structures have so far been established under the regional human rights treaties in Europe, the Americas, and Africa where regional human rights courts and commissions have been granted substantial review and remedial powers. After a modest start, these regional human rights commissions and courts have evolved in an increasingly dynamic manner, a development that has placed them at the centre of the debate on the scope and effectiveness of IHRL today. ${ }^{4}$ Far from limiting themselves to the examination of individual cases of rights violations, the regional bodies have also begun to address general and systemic problems in the area of human rights protection, ranging from more technical matters like deficiencies in the effective implementation of the right to a fair and speedy trial to politically highly sensitive human rights issues.

As a result of these processes, IHRL has become the paradigm of a profound transformation of the international order, from a system of rules and practices primarily designed to accommodate the interests and rights of states to an international legal system based on a number of fundamental values, respect for the dignity and the basic rights of individuals foremost among them. ${ }^{5}$ Not surprisingly, this development has also turned international human rights and their enforcement into a key battleground in the debate on the continuing relevance of the liberal paradigm of international law, a paradigm which was widely seen as triumphant in the first decades following the collapse of communism and the end of the Cold War, but has come under increasing pressure from nationalist groups advocating a return to a state and sovereignty-centered understanding of international law more recently. Against this background, compliance research can be seen as central to answering some of the key questions related to the current state of health of IHRL, and liberal international law more generally: to what extent has the promise of a more effective protection of individual rights through the international monitoring and supervision been realized in practice, and how has the effectiveness of IHRL been affected by the recent backlash against international cooperation and international institutions fueled by the renaissance of populism and neo-sovereigntism?

What is at stake here was pointed out by Kal Raustiala and Anne-Marie Slaughter in their seminal article on compliance in the first edition of the Handbook of International Relations:

In the end ... the study of compliance ... implicitly examines the foundations of international institutions and of international order. If compliance with international rules is ephemeral, or results purely from the exercise of power and coercion, the ability of international law and institutions to order world politics is greatly limited. Conversely, if compliance is empirically demonstrable, theoretically understandable and prescriptively manageable, then the case for the role of international law and institutions in achieving global order is strong. ${ }^{6}$

4 On the dynamic evolution of the regional systems see Alexandra Huneeus and Mikael Rask Madsen, 'Between Universalism and Regional Law and Politics: A Comparative History of the American, European, and African Human Rights Systems' (2018) 16 International Journal of Constitutional Law 136; Başak Çali, 'Explaining Variation in the Intrusiveness of Regional Human Rights Remedies in Domestic Orders' (2018) 16 International Journal of Constitutional Law 214.

5 On the assumptions of the liberal theory of international law generally see Anne-Marie Slaughter and José E. Alvarez, 'A Liberal Theory of International Law' (2000) 94 Proceedings of the Annual Meeting of the American Society of International Law 240-1.

6 Kal Raustiala and Anne-Marie Slaughter, 'International Law, International Relations and Compliance' in Walter Carlsnaes, Thomas Risse and Beth A. Simmons (eds), Handbook of International Relations (SAGE 2002) 553. 


\section{THE CONTINUING RELEVANCE OF COMPLIANCE IN INTERNATIONAL HUMAN RIGHTS LAW RESEARCH}

Since Louis Henkin's seminal book 'How Nations Behave' in 1968, which is generally considered as its starting point, ${ }^{7}$ research into compliance with international law has constantly grown and developed along several lines at the border between international law and international relations. ${ }^{8}$ However, especially in the last two decades, several and prominent voices in international law scholarship have expressed serious objections to the growing preoccupation of contemporary international legal scholarship with the study of compliance. ${ }^{9}$

A first critique essentially questions the usefulness of compliance as a conceptual and empirical category to measure the effectiveness of international law. To better understand this criticism, a clarification of the meaning of compliance and neighbor concepts is necessary. According to the leading definitions by Raustiala and Slaughter, compliance is defined as 'a state of conformity or identity between an actor's behavior and a specified rule'. ${ }^{10}$ Compliance is, therefore, to distinguish from 'implementation', which denotes 'the process of putting international commitments into practice', ${ }^{11}$ as well as from 'enforcement', which refers to those activities which are intended to push relevant actors towards a rule-compliant behavior, e.g. through the imposition of sanctions. But 'compliance' is above all to distinguish from 'effectiveness', which can be defined as 'the degree to which a rule induces changes in behavior that further the rule's goals' ${ }^{12}$

If compliance is understood as a mere state of conformity between a rule and a behavior, then 'the sheer existence (or lack) of compliance may indicate little about international law's impact on behavior'. ${ }^{13}$ High compliance with international law may correspond to little or no effectiveness of it when rules simply reflect pre-existing behaviors and are not meant to change them. Conversely, rules showing a low level of compliance can nevertheless be very

7 ibid, 540.

8 Several reviews exist of compliance literature in law and political science: see, in particular, Benedict Kingsbury, 'The Concept of Compliance as a Function of Competing Conceptions of International Law' (1998) 19 Michigan Journal of International Law 345; Raustiala and Slaughter (n 6); Lisa L. Martin, 'Against Compliance' in Jeffrey L. Dunoff and Mark A. Pollack (eds), Interdisciplinary Perspectives on International Law and International Relations. The State of the Art (CUP 2012) 591; Ingrid Wuerth, 'Compliance' in Jean d'Aspremont and Savinder Singh (eds), Concepts for International Law. Contributions to Disciplinary Thought (Edward Elgar 2019) 117.

9 George W. Downs, David M. Rocke and Peter N. Barsoom, 'Is the Good News About Compliance Good News about Cooperation?' (1996) 50 International Organization 379; Howse and Teitel (n 1); Martin (n 8); Timothy Meyer, 'How Compliance Understates Effectiveness' (2014) 108 Proceedings of the ASIL Annual Meeting 93; Jeffrey L. Dunoff, 'Is Compliance an Indicator for the State of International Law? Exploring the "Compliance Trilemma", in Heike Krieger, Georg Nolte and Andreas Zimmermann (eds), The International Rule of Law. Rise or Decline? (OUP 2019) 183. With specific reference to the Inter-American human rights system see Armin von Bogdandy and Rene Urueña, 'International Transformative Constitutionalism in Latin America' (2020) 114 American Journal of International Law 425 ff.; for the European system see David Kosař, Jan Petrov, Katarína Šipulová, Hubert Smekal, Ladislav Vyhnánek and Jozef Janovský, Domestic Judicial Treatment of European Court of Human Rights Case Law. Beyond Compliance (Routledge 2020).

10 Raustiala and Slaughter (n 6), 539.

11 ibid.

12 ibid.

13 ibid. 


\section{Research handbook on compliance in international human rights law}

effective, when they are meant to eradicate deeply rooted behaviors. From this perspective, compliance has been criticized as 'a legal concept that is unusually ill-suited to ... the identification and measurement of causal effects ${ }^{14}$ or it has been argued that 'an excessive focus on compliance may understate international law's effectiveness' ${ }^{15}$ In sum, what matters is not compliance with international law but international law's impact on states' behavior.

A second, more subtle, critique argues that focusing on compliance 'obfuscates the character of international legal normativity, tending to ignore the centrality of interpretation to the generation of legal meaning ...' ${ }^{16}$ In this view, 'interpretation' rather than 'compliance' should be given central importance to understanding the working of international law:

Interpretation is pervasively determinative of what happens to legal rules when they are out in the world; and yet 'compliance' studies begin with the notion that to look at effects, we start with an assumed stable and agreed meaning to a rule, and whether it is complied with or obeyed, so understood. ${ }^{17}$

While these criticisms are helpful to put the potential benefits of compliance research into perspective, they lose much of their strength if applied to IHRL and notably to compliance with the judgments of regional human rights courts, which is the focus adopted in this book.

The distance between compliance and effectiveness, which can be pronounced with respect to treaty law, tends to disappear when compliance with a judgment is at stake. As Alexandra Huneeus rightly points out,

when a state complies with a court judgment, there is a detectable change in behavior ... In this scenario, it is less fraught to assume that the behavior constituting compliance is an outcome of the decision, and that it goes against a fairly strong reason for non-compliance (strong enough to justify the risk of a negative international ruling). Similarly, when a court orders a state to pay a specific amount of compensation to a victim of a human rights violation, for example, and the state pays precisely the amount in question, causality is less fraught. The answer to the counterfactual 'Would the state have done the same without the order?' - seems self-evident. ${ }^{18}$

Also, the relationship between interpretation and compliance proves to be very peculiar in this field. Here, the normative indeterminacy of rules protecting broadly worded rights and freedoms tends to be even greater than in other fields of international law. But a specific feature of the regional systems of human rights is the establishment of regional courts that have been entrusted with the task of interpreting these open-ended human rights provisions so that the obligations falling on the states are the result of the interpretation by the regional human rights courts.

Thus, while compliance cannot embrace and explain all the impacts of international law on states' behavior and beyond, there are still good reasons to keep it as a guiding concept for the study of IHRL, and of the three regional human rights systems in particular. However, if it is to yield meaningful results, compliance research must address the specific challenges and prob-

\footnotetext{
Martin (n 8) 591.

Meyer (n 9) 93.

Howse and Teitel (n 1) 128.

ibid, 135.

18 Alexandra Huneeus, 'Compliance with Judgments and Decisions' in Cesare P.R. Romano, Karen J. Alter and Yuval Shany (eds), The Oxford Handbook of International Adjudication (OUP 2014) 441.
} 
lems raised by IHRL. In particular, the specific nature of international obligations generated by human rights treaties, as well as their content, and the institutional design of the respective treaty regimes have to be taken into account.

With regard to the nature of IHRL obligations, a unique feature of international human rights treaties is that they 'create stakeholders almost exclusively domestically'. ${ }^{19}$ Put differently, 'human rights law governs the vertical relationship between states and constituents, not the horizontal relationship between states'. ${ }^{20}$ The enforcement of human rights treaties relies essentially on the initiative of domestic actors, i.e. the individuals to whom the rights and freedoms recognized in the treaties are to be secured, and the groups and organizations which are ready and willing to assist them in the defense of their rights. Similarly, compliance with an international ruling that the petitioner's rights have indeed been violated requires domestic action to put an end to the human rights violation in question, either through a judicial decision or executive intervention or, if the ruling identifies structural defects in the domestic arrangements for human rights protection, through legislation. In the words of Courtney Hillebrecht, 'compliance with international human rights tribunals' rulings is an inherently domestic affair'. ${ }^{21}$ This suggests a focus in compliance analysis of IHRL which gives equal weight and attention to transnational dynamics - how do states exposed to international human rights norms behave vis-a-vis the international institutions charged with monitoring and enforcing them - and to the complex domestic legal and political arrangements and processes which shape the implementation of those norms at the local level. ${ }^{22}$

With regard to their content, international human rights treaties impose comprehensive and potentially far-reaching demands on member states, as the commitments undertaken by states under a human rights treaty affect most, if not all, areas of state activity. Thus it is impossible to know in advance the full range of measures a state party will have to take to achieve full compliance with its commitments under the respective treaty. Compliance with the obligations contained in an international human rights treaty is thus necessarily a highly dynamic and open-ended process.

This is reflected in the design of the international institutions set up by the various human rights treaties to monitor the implementation of treaty obligations by state parties. Here a major difference exists between the universal human rights treaties concluded under the auspices of the UN and the more advanced regional human rights treaty systems, namely the European, Inter-American and African systems. While the mainstreaming of human rights has been one of the major concerns of political and diplomatic strategies at the UN level since the 1990s, its dynamics have not matched the breadth and depth of the parallel processes at the regional level. This explains why this book focuses essentially on the three regional human rights systems.

The universal human rights treaty regimes are still stuck with the periodic reporting system and peer review mechanisms, allowing only for a narrowly circumscribed use of quasi-judicial

19 Beth A. Simmons, Mobilizing for Human Rights: International Law in Domestic Politics (CUP 2009) 126; Alice Donald and Patrick Leach, Parliament and the European Court of Human Rights (OUP 2016) 68.

20 Courtney Hillebrecht, Domestic Politics an International Human Rights Tribunals - The Problem of Compliance (CUP 2014) 3.

21 ibid, 3.

22 Donald and Leach (n 19) 68. 
expert opinions to assess compliance in specific contested cases. The only compulsory monitoring mechanism which the specialized UN human rights committees can use is the state reporting procedure. It consists in the examination by the committee of the state reports on the progress made in the implementation of treaty obligations submitted by state parties in periodic intervals and concludes with the non-binding observations addressed by the committee to the member states concerned on the progress or lack thereof in the discharge of their treaty obligations. The individual communications procedure, on the other hand, applies only to those state parties which have formally accepted it. The committees occasionally use this procedure to check not only whether there has been a violation of the rights of the applicant but also to indicate appropriate relief measures, such practice does not give rise to a binding obligation of the state party to implement the measure indicated by the committee: the state party is only expected to consider the holdings of the committee on the merits of the individual communication in good faith.

The situation is quite different with regard to the regional human rights systems. They have established human rights monitoring bodies and, in particular, the regional human rights courts which have the power to review individual petitions and to issue binding decisions whether a state party has complied with its treaty obligations or not. However, important differences continue to exist between the three regional systems, as the first chapters of each part of this book will explain in detail. Only in the European system is the individual petition procedure compulsory. In the Inter-American system, the jurisdiction of the Inter-American Court of Human Rights (IACtHR) to review individual petitions referred to it by the Commission is still dependent on the recognition by the respondent state (which may be withdrawn), although the huge majority of the member states has made such a declaration. In the African system, where the acceptance of the jurisdiction of the African Court on Human and Peoples' Rights to review individual petitions is optional, only a small minority of member states have made a declaration to this effect and, of these, some have already withdrawn it.

Major differences also exist between the regional human rights courts with regard to the remedial measures they may order in case they find a violation of treaty obligations by a state party. ${ }^{23}$ The IACtHR may order a wide range of measures, from symbolic gestures to financial compensation, the invalidation of legislation or the prosecution of the perpetrators of human rights violations. The European Court of Human Rights (ECtHR), by contrast, can only declare whether an individual has had his or her rights violated, but may not order specific measures of redress - apart from financial compensation if a full restoration of the status quo ante is impossible. The state party which has been found in violation of one or several provisions of the Convention must thus 'reason backwards from the violation to understand the appropriate remedy in a specific case, and the actions required to avoid similar future violations'. ${ }^{24}$ As the ECtHR has materially expanded its jurisprudence over the years these initial arrangements have proved increasingly awkward, and the ECtHR has tried to relax them at least partially by introducing new forms of judgments and orders.

23 Çali (n 4).

24 Darren Hawkins and Wade Jacoby, 'Partial Compliance - A Comparison of the European and Inter-American Courts of Human Rights' (2010) 6 Journal of International Law and International Relations 51. 


\section{MEASURING COMPLIANCE: METHODOLOGICAL ASPECTS}

Even if the focus is narrowed from compliance with IHRL to compliance with specific judicial decisions spelling out the precise scope of the obligations under IHRL, the measuring of compliance remains a highly complex undertaking.

As outlined by Huneeus, compliance is a relational concept referring to a correspondence between the ruling's demands and the behavior of the parties subject to the ruling. ${ }^{25}$ Thus, 'measuring judgment compliance requires at least three separate steps: an interpretation of what behavior the ruling demands and of whom; an assessment of the subject parties' behavior; and a comparison of the two' ${ }^{26}$

Already when it comes to evaluating whether a single judgment against a specific state has been complied with, each of these three steps raises complex interpretative and measurement challenges. ${ }^{27}$ But things get even more complicated in at least two scenarios that are particularly relevant in the regional human rights systems. The first one is when a judgment does not deal with a specific violation of a specific right in an individual case, but points at a systemic or structural deficiency in the human rights protection of the defendant state, so that compliance requires complex and deep reforms. The second refers to the duty of state parties to the conventions not only to comply with the judgments directly affecting them but also to take into account the court's case-law against other states, i.e. to consider how the convention has been developed by the court and to ensure that violations found in relation to other state parties are avoided within their own jurisdiction. In both cases, the assessment of the correspondence between the judgment(s) and the state behaviour involves complex operations.

The notion of 'partial compliance' can be useful to overcome the difficulties in measuring compliance. Such a notion has been first introduced in compliance research by the seminal article of Darren Hawkins and Wade Jacoby, as a way to 'break down the dichotomy between compliance and non-compliance' ${ }^{28}$ With reference to compliance with the judgments of the ECtHR and the IACtHR, they suggest that 'partial compliance appears to be a relatively stable end point in many ... cases - one that is more common than it is often supposed'. ${ }^{29}$ This intermediate category certainly gives a more precise and nuanced picture of compliance but it does not solve all methodological challenges of measuring compliance.

To cope with the difficulty of measuring compliance, the contributions in this book take the observations of the treaty body or court competent to supervise compliance as a starting point. Important differences exist between the regional human rights systems in this regard. In the Inter-American system, it is the IACtHR itself that monitors compliance with its judgments, and regularly publishes compliance reports on the progress made in the implementation of a judgment. ${ }^{30}$ By contrast, in the European system it is not the ECtHR, but the Committee of Ministers (CM), a political body, which supervises the execution of the Court's rulings

\footnotetext{
25 Huneeus (n 18) 443.

26 ibid.

27 ibid.

28 Hawkins and Jacoby (n 24) 36.

29 ibid.

30 Rene Urueña, 'Compliance as transformation: the Inter-American system of human rights and its impact(s)' in this Volume.
} 
(Article 46(2) ECHR). Following a 'dialogue' with the concerned state, it closes the case if it is satisfied that the required individual or general measures to correct the violation and prevent its recurrence have been taken and the amount of just satisfaction has been paid. ${ }^{31}$ Thus, the assessment of whether, and to what extent, compliance has occurred in any given case starts with the official assessments by the IACtHR, by the CM, and by the African Court, respectively.

However, the assessment of compliance by authorities legally responsible to monitor compliance in the three regional systems cannot be viewed as being conclusive on the matter. As for the European system, it must be borne in mind that the CM is a political body, and the discussions with the state party in the supervision of a judgment by the Court may well take the form of protracted diplomatic and political negotiations which sometimes can only be concluded by way of compromise..$^{32}$ In the Inter-American system, where the IACtHR has taken the supervision of the implementation of its judgments into its own hands, considerations of political expediency play a less visible role, as the court can be assumed to function according to a judicial logic not only when it deliberates on its rulings, but also when it supervises their implementation. But it is still worth remembering that the broad label of 'partial compliance' can refer to very different degrees of compliance, ranging from almost no action by the affected state (for example, when the state confines itself to publishing the IACtHR decision) to significant and effective changes in domestic legislation that nevertheless do not amount to full compliance. ${ }^{33}$

In the light of these considerations, the contributors to this book have been asked to discuss these results critically, bearing in mind that even in cases that have been officially closed compliance might not have been fully achieved - for example, because the case was closed for political reasons - while on the other hand a case may still be on the agenda despite serious efforts to comply being made by the responding state. This is an area where compliance with IHRL touches on the related, but distinct concept of impact of IHRL, an issue to which the concluding chapter will return. ${ }^{34}$

\section{STRUCTURE OF THE BOOK}

The structure of this book reflects the considerations on the usefulness of compliance for understanding international law in general, and IHRL in particular, outlined above.

First, it focuses on those human rights treaty regimes which have developed a comparatively strong adjudicatory system, i.e. on the regional human rights treaties and courts in Europe, the Americas, and Africa, examined in chronological order, from the oldest to the newest system (Parts I to III). The monitoring mechanisms and practices as they have developed under the

\footnotetext{
31 Raffaela Kunz, 'Securing the survival of the system: the legal and institutional architecture to supervise compliance with the ECtHR's judgments' in this Volume.

32 The British prisoner voting rights case is a recent example: see Alice Donald, 'Compliance in the UK in the age of "subsidiarity" in this Volume, section 5.1.

33 Urueña (n 30) section 2.2. For a critique see already Courtney Hillebrect, 'Rethinking Compliance: The Challenges and Prospects of Measuring Compliance with International Human Rights Judgments' (2009) 1 Journal of Human Rights Practice 366.

34 See also 'Conclusions: moving beyond compliance without neglecting compliance in international human rights law', in this Volume.
} 
various human rights treaties at the global level are only discussed exemplarily, using the International Covenant on Civil and Political Rights as a model (Part IV). The book thus forms part both of the research on compliance within regional human rights systems ${ }^{35}$ and the growing literature comparing the regional human rights systems with each other. ${ }^{36}$

Second, we look at the institutional design and legal processes to secure compliance both at the regional and at the national level. Each of the three following Parts is opened by a chapter that analyses and puts into context the main institutions and mechanisms for promoting and strengthening compliance in the European, Inter-American, and African systems. They examine the regional human rights systems as designed by the corresponding human rights Conventions and as shaped by the practice of their apex courts. They outline the obligations that they impose on the state parties and discuss the monitoring and enforcement mechanisms at the disposal of the supranational authorities, particularly stressing the efforts made by the three courts to foster domestic compliance with their judgments.

These introductory chapters are followed by country studies discussing the constitutional arrangements and the political and social dynamics of domestic compliance in selected member states. The selection of the relevant national jurisdictions is based on a combination of criteria taking into account geographical diversity as well as the special relevance of particular countries with regard to compliance. For example, concerning Europe, we included countries with a good (Germany) and a less good record of compliance (Russia), countries where Parliament plays the main role in compliance (the UK) and countries where judicial compliance prevails (Italy), smaller and bigger countries, countries where the ECHR enjoys constitutional status (Austria) and countries where courts resort to other techniques to review compliance with the Convention (e.g. Spain). Similar considerations apply to the choice of Latin American countries. If Africa is represented only with two countries, this reflects the fact that the African court's jurisdiction has been accepted only by a small and rapidly dwindling number of countries, which also means that a central focus of this book - domestic compliance with the judgments of the regional human rights courts - has been subject to much less attention and debate than in the other two regions.

35 For the European system, see, e.g.: Helen Keller and Alec Stone Sweet (eds), A Europe of Rights: The Impact of the ECHR on National Legal Systems (OUP 2008); Giuseppe Martinico and Oreste Pollicino (eds), The National Judicial Treatment of the ECHR and EU Laws. A Constitutional Comparative Perspective (Europa Law Publishing 2010); Dia Anagnostou (ed), The European Court of Human Rights. Implementing Strasbourg's Judgments on Domestic Policy (Edinburgh University Press 2013); Anja Seibert-Fohr and Mark E. Villiger (eds), Judgments of the European Court of Human Rights. Effects and Implementation (Routledge 2014); Janneke H. Gerards and Joseph Fleuren (eds), Implementation of the European Convention on Human Rights and of the Judgments of the ECtHR in National Case-Law. A Comparative Analysis (Intersentia 2014). For the Inter-American system: Viviana Krsticevic, Implementación de las decisiones del Sistema Interamericano de Derechos Humanos Aportes para la Administración de Justicia (CEJIL 2016); Par Engstrom (ed), The Inter-American Human Rights System: Impact Beyond Compliance (Palgrave Macmillan 2019); Víctor Bazán and Marie-Christine Fuchs (eds), Ejecución, nivel de cumplimento e implementación de sentencias de tribunales constitucionales y cortes supremas en la región (Tirant lo Blanch 2020). For the African system: Rachel Murray and Debra Long, The Implementation of the Findings of the African Commission on Human and Peoples' Rights (CUP 2015).

36 See Başak Çali, Mikael Rask Madsen and Frans Viljoen, 'Comparative Regional Human Rights Regimes: Defining a Research Agenda' (2018) 16 International Journal of Constitutional Law 128; Laurence Burgorgue-Larsen, Les 3 Cours régionales des droits de l'homme in context. La justice qui n'allait pas de soi (Pedone 2020). 
Mention should be made that we included in our selection at least three countries that now openly reject the liberal paradigm of international law - Hungary, Russia, and Venezuela although not all of them have left the respective regional human rights system (yet). These chapters follow a slightly different approach than the others. Instead of, or next to, examining how constitutional arrangements can foster compliance, they investigate how and to what extent a constitutional setting can prevent or slow down a direct attempt by a strong political power to depart from the principles of IHRL.

Third, in the country studies, separate consideration is given to the different role of the different branches of government within the constitutional system (the executive, the legislature and the courts) as well as to the role of civil society organizations. This approach reflects the growing tendency of the regional courts to refine the operative part of their decisions in line with the specific responsibilities of the different branches of government. In addition, the political branches, the judiciary, and civil society each follow their own distinct attitude and logic in their approach to compliance. A thorough examination of their contribution to the promotion of compliance is vital to understanding the legal, political, and social dynamics of domestic compliance with IHRL.

Within the limits imposed by the respect for the contributors' scientific freedom, all national reports follow the same structure. At first, they explain the status of IHRL in the country's constitutional setting, particularly stressing the place and the binding effect that the state acknowledges to the judgments of the three regional human rights courts. A detailed examination of the role of the different branches of government follows. As for the political branches, the executive and parliament, the national reports address questions like whether there are specialized bodies to secure compliance, whether specific procedures have been set up to secure that judgments are implemented and legislation is in line with IHRL, whether parliamentary minorities have legal tools at their disposal to foster the ruling majority to comply, and so on. As for the courts, the reports examine whether and to what extent domestic courts follow, or at least take into account judgments dealing with human rights violations by their own state, but also those addressed to another state party concerning a human rights issue which they also encounter within their normal legal system. Particular emphasis has been put on the division of labor within the judiciary, which frequently assigns a peculiar role to supreme or constitutional courts. Finally, each chapter examines civil society's organizations' vital contribution to turning IHRL from dead letters into living instruments, an issue that has received little attention so far.

The three cross-cutting chapters in Part V, each authored or co-authored by one of the book's editors, build on the distinction between the political branches, the judicial branch, and civil society organizations which is used to structure the country studies, and take stock of the findings from Parts I to III.

The concluding chapter summarizes the main results of the preceding Parts of the book and discusses some of the trends and issues likely to shape the debate in the years ahead, in line with the general objective of this Research Handbook which, by providing a comprehensive and up-to-date picture of the main insights generated by compliance research in IHRL so far, aims to facilitate a broad discussion on the future research agenda in the field. 